\title{
Gaining a Deep Understanding of the Contemporary Significance of the Strategy of "Exercising Strict Governance over the Party"
}

\author{
Yi Zhang ${ }^{1}$, Hongtao Shan ${ }^{1}$, Junfei Bi ${ }^{1}$, Mengqi Zhang ${ }^{1}$, Hui Liu ${ }^{1}$, Zi Wang ${ }^{1}$ \\ ${ }^{1}$ Experimental Training Base College of information and Communication National University of Defense Technology \\ Xi'an, China, 710106 \\ Email:1774997983@qq.com
}

\begin{abstract}
"Exercising strict governance over the Party" is an overarching strategy proposed at the 18th National Congress of the CPC. It is an important part of the "Four Comprehensives" strategy and constitutes the fundamental guarantee for building a moderately prosperous society in all respects, for deepening the reform comprehensively and for comprehensively promoting law-based governance. Therefore, gaining a deep understanding of the contemporary significance of the strategy of "exercising strict governance over the Party" is of great importance in insisting on the path of socialism with Chinese characteristics and realizing the Chinese Dream of national rejuvenation.
\end{abstract}

Keywords: Exercising strict governance over the Party, Leadership of PC, Chinese Dream

\section{THE STRATEGY OF "EXERCISING STRICT GOVERNANCE OVER THE PARTY" IS PROPOSED BASED ON THE HISTORICAL LESSONS OF THE DEMISE OF THE COMMUNIST PARTY OF SOVIET UNION (CPSU).}

It has been 29 years since the demise of the Communist Party of Soviet Union (CPSU), but the lessons it left behind never fade away with time. Every time when the reform and development of China come at an important moment, senior leaders of the CPC would bring this scar on the history of international communist movement, reminding us not to forget it. Mr. Xi Jinping, President of the People's Republic of China and General Secretary of the CPC, has solemnly pointed out that "our country is similar or identical to Soviet Union in terms of institution, system, path and situations that we face today. If we make it well, we'll have a bright future; otherwise, Soviet Union's yesterday will be our tomorrow!" We will see that President Xi's warning is not an overstatement if we reflect the lessons of the demise of the CPSU profoundly and examine the situations and tasks ahead of us objectively [1].

The lessons of the demise of the CPSU should be looked for from the reasons of its demise. It is widely believed that the demise of the CPSU is contributed by both international reasons and internal reasons, and that internal reasons play the main cause, which is the basis of changing. On this issue, Mr. Deng Xiaoping has clearly pointed out that "the disintegration of Eastern Europe is no surprising for us, which is only a matter of time. The problem of Eastern Europe starts from inside." The demise of the CPSU is fundamentally caused by a highly centralized political system. According to former leader of the Communist Party of Russian Federation Gennady Zyuganov, the disadvantages of the highly centralized system of Soviet Union can be summarized as "three monopoly institutions", namely, a political and legal monopoly on power, an administrative monopoly on resources and economic benefits and an ideological monopoly on truth. Specifically, monopoly power is manifested as absolute appointment system at cadre posts and life tenure at leading posts; monopoly truth is manifested as monopoly of discourse and patriarchy, and monopoly benefits is manifested as a serious phenomenon of privilege. Absolute power will definitely accelerate the change of officials and cadres from "public servants" to "masters", induce them to plunder state property and cause prevailing corruption. This is the second, but the decisive reason for the demise of the CPSU. In addition, the deep reason is that senior CPSU officials and cadres betrayed their political beliefs. The convictions of some senior party officials began to shake and collapse, including Nikita Khrushchev, former 
secretary of the CPSU, and finally they betrayed their political faiths completely [2]. A survey conducted in June 1991 showed that $76.7 \%$ of senior CPSU cadres believed that capitalism institution should be adopted! How can desperate Soviet Union people support the Party if the largest stakeholders of CPSU feel no lingering for their communist country? Huang Weiting, a famous party research expert, conducted a thorough research on the demise of the CPSU and concluded that the Communist Party of Soviet Union is crushed by both international and internal reactionary forces and abandoned by those people whom it represents, and the later one is the decisive reason. So, what lessons does the demise of the CPSU leave behind?

Lesson 1: A party and a country may deteriorate if democratic centralism is not applied. Democratic centralism is the organizing principle of communist party. Party members and cadres will inevitably cut themselves off from the people and become minority or personal arbitrary if democratic centralism is not adopted. Internally, the crashing point of CPSU started from the disapproval of democratic centralism, political polarization represented by the top leader of the CPSU was formed gradually, the future and destiny of the Party and state were determined by the will of the top leader, and finally the CPSU, a communist party with a history of 70 years, was dissolved easily by a general secretary.

Lesson 2: There is no reliable organization guarantee for the cause of the communist party if cadre team is not strongly constructed.

Absolute appointment system at cadre posts and life tenure at leading posts within CPSU devitalized cadre system and created a style of power worship, inducing party members plunder wealth and benefits with power without concerning the cause of the party.

Lesson 3: Corruption may destroy a party and a country if it continues without timely governance. From the Stalin era on, the phenomenon of privilege emerged, bigwigs started to develop, and corruption was growing more and more serious, which seriously damaged the body of the party. The seniors of the CPSU had realized the seriousness of corruption, but they took negative attitudes toward it and made no decisive and practical efforts to control, and finally the further of the party was ruined.

Lesson 4: Some big problems will happen if ideological construction is neglected. The Communist Party of Soviet Union was guided by Marxism at first, but the guiding thoughts multiplied gradually as ideological building was neglected, and finally Soviet Union changed the flag authorities under the strong attack of peaceful evolution by western countries.
The lessons of the demise of the CPSU told us that our party can keep thriving and prosperous all the time only when we ensure that the Party exercises effective self-supervision and practices strict self-governance in every respect. It takes good iron to make good products.

\section{THE STRATEGY OF "EXERCISING STRICT GOVERNANCE OVER THE PARTY" IS PROPOSED IN THE COURSE OF REALIZING CHINESE DREAM}

The key to managing affairs well in China is the Party. The cause of the Party, the country and the nation will be strong only when the Party is strong. Exercising full and rigorous governance over the Party is a strategic consideration and fundamental guarantee for realizing the "Two Century" goals and Chinese Dream of national rejuvenation, and it is also a distinct characteristic of the governance of the CPC central committee with Xi Jinping at its core.

\subsection{To ensure that the Party remains a powerful leadership core in the course of realizing Chinese Dream, it is crucial to strengthen the Party's advanced nature.}

Strengthening the advanced nature of the party was taken as a goal of party building since the birth of Marxist political party. Marx and Engels, in their The Communist Manifesto, argued that "the Communists, therefore, are on the one hand, practically, the most advanced and resolute section of the working-class parties of every country, that section which pushes forward all others". The Communist Party of China has always attached great importance to the construction of the Party's advanced nature since its birth. In the new democratic revolution period, concerning the specific context and historical responsibilities, the CPC required that all levels of party organizations and members to play a pioneering role in democratic revolution and national liberation. In the period of social revolution and construction when the world socialist movements and national liberation movements surged and China was faced with the task of rebuilding, the CPC required that all levels of party organizations and members to play an advanced and model role in social transformation and new world construction. In the period of reform and opening up and socialist modernization when peace and development became the epoch topic of the times and China entered the primary stage of socialism, the CPC required that all levels of party organizations and members to be models to emancipate their minds, to explore and to innovate. Over the past ninety years, the CPC has always put the building of the Party's advanced nature in the first place, so that our Party manages to stand out in the long-term political struggles and battles and to promote the cause of our country forward step by step. However, the advanced nature of a party is not an inherent property or something 
once and for ever, it is a process of continuous learning, practicing and improving. Achieving national rejuvenation will be no walk in the park. Our Party must be ready to protect against potential dangers and alert to dangers even in times of peace, only thus can our Party remain a powerful leadership core in the course of realizing Chinese Dream.

\subsection{In a context where both China and the world are in the mist of profound and complex changes, to ensure that the Communist Party of China provides a good international and domestic environment for achieving Chinese Dream, it is critical to strengthen the Party's advanced nature.}

The development of times and practice creates many new demands for the Party's advanced nature building. Internationally, although peace and development have become the epoch topics of the contemporary world, the international situation is still in the mist of profound and complex change, the world political and economic patterns have undergone new changes, and new trends have arisen in international power dynamics. Politically, the communist movements suffered serious setbacks after the collapse of the former Soviet Union and tremendous change to East Europe, and western hostile forces never gave up attempts to overthrow communist countries through peaceful evolution or even military forces, which placed the cause of communist in low ebb. Economically, western developed countries are still dominating in the fields of economy and technology, and international competition is changing to an overall competition with economy as the basis and high technology as the focus, in which respect China has no advantages. What's more, hegemonism and power politics become a world security hazard, terrorism is rampant, local wars and conflicts continue, and global environmental problems are becoming increasingly acute, posing a serious threat to human survival and development [3]. Domestically, our country has entered a new era of socialism with Chinese characteristics. Although the comprehensive strength of our country has been significantly enhanced and the people's living standards have been remarkably improved, we are still faced with many new situations and new problems. In short, the major changes of international and domestic situations bring a huge challenge to the construction of the Party's advanced nature, in which context it is required that the Communist of China must conduct education on keeping the Party's advanced nature, seize opportunities to meet the challenges and take the upper hands, and to further advance the building of the Party's advanced nature, so as to provide a good international and domestic environment for realizing Chinese Dream.
2.3. To ensure that the CPC remains at the forefront of the times and keeps vigorous and enthusiastic in the course of achieving Chinese Dream, it is crucial to strengthening the Party's advanced nature.

Standing at the forefront of the times is the inherent requirement of Party's advanced nature and also the fundamental guarantee for ensuring the $\mathrm{CPC}$ as a powerful leadership core of socialism with Chinese characteristics. According to recent statistics from the Organization Department of the CPC Central Committee, there are 91,914,000 members of the CPC in total by the end of 2019, and there are 4,681,000 primary party organizations at present [4]. In the contemporary times, for such a huge party, the CPC is well qualified for undertaking the historic tasks with its leadership, governance capacity, party building and member quality. However, concerning complex changes of international and domestic situations as well as the double tests of long-term governance and reform and opening-up, there are still new situations and new problems in terms of ideology, quality and capacity in the Party's cadre team. For example, under the influence of the socialist market economy and western thoughts, some party members and cadres are incapable of exercising state power according to law and are not alert to potential risks in long-term governance, the reach of party organizations is not as extensive as required, party organizations are loosely managed without robust supervision and smooth mechanism, role positioning of party members is not clear, and work quality is quite low. These prominent problems in the Party, although not occupying the mainstream status, severely undermine the advanced nature of our Party [5]. To ensure that our Party remain at the forefront of the times and keep vigorous and enthusiastic in the course of achieving Chinese Dream, it is critical to strength the Party's advanced nature and stay motivated in pioneering and pushing ahead, so that our Party can withstand the tests of governance, reform and opening-up and external environments, and keep forging ahead in the context where the world trends are in the mist of profound changes.

\section{THE STRATEGY OF "EXERCISING STRICT GOVERNANCE OVER THE PARTY" IS PROPOSED IN THE CONTEXT OF ACTIVELY TACKLING ISSUES AND CHALLENGES WITHIN THE PARTY}

As socialism with Chinese characteristics has entered a new era, exercising strict governance over the Party is a journey to which there's no end. In the speech delivered at the 19th CPC National Congress, Mr. Xi pointed out that the whole party must soberly aware that the governance environment our Party faces is complex, and that prominent problems of impurity in thinking, 
organization, and conduct in the Party have not been solved root and branch. We must fully recognize the longterm and complex nature of the tests confronting the Party as they relate to governance, reform and opening up, the market economy, and the external environment. We must also fully recognize the intensity and severity of the dangers of a lack of drive, incompetence, disengagement from the people, inaction, and corruption[6]. Thus, we must focus on solving problems, maintain strategic resolve, and ensure strict Party self-governance.

The general requirements of Party building in new era are upholding and strengthening overall Party leadership and ensuring that the Party exercises effective selfsupervision and practices strict self-governance in every respect; taking strengthening the Party's long-term governance capacity and its advanced nature and purity as the main thrust; taking enhancing the Party's political building as the overarching principle; taking holding dear the Party's ideals, convictions, and purpose as the underpinning; taking harnessing the whole Party's enthusiasm, initiative, and creativity as the focus of efforts; making all-round efforts to see the Party's political building enhanced, its theory strengthened, its organizations consolidated, its conduct improved, and its discipline enforced, with institution building incorporated into every aspect of Party building; stepping up efforts to combat corruption and continue to improve the efficacy of Party building; building the Party into a vibrant Marxist governing party that is always at the forefront of the times, enjoys the wholehearted support of the people, has the courage to reform itself and is able to withstand all tests.

\section{CONCLUSION}

We should be guided by Xi Jinping thought on Socialism with Chinese characteristics for a New Era. Comprehensively promote Party building comprehensive exercising of self-governance of the larger strategic results to celebrate the 100th anniversary of the founding of the Communist Party of China with outstanding achievements.

\section{REFERENCES}

[1] Research Office of History of Chinese Communist Party. 90 Years of the Communist Party of China (in Chinese) $[\mathrm{M}]$. History of Chinese Communist Party Publishing House, 2016.

[2] Wei, Song. "New Understanding, New Trends and New Strategies on the Building of the Party's Work Style (in Chinese)". Chinese Cadres Tribune Sponsor [J], Vol. 1, 2020.

[3] Xiaoping, Deng. Deng Xiaoping Selected Works (in Chinese) [M]. People's Publishing House, 1994.
[4] Publicity Department of the Communist Party of China Central Committee. An outline for the study of Xi Jinping Thought on Socialism with Chinese Characteristics for a New Era (in Chinese) [M]. Xuexi Publishing House, People's Publishing House, 2019.

[5] Yingqing, Huang. "Study on Political Construction in the Context of Exercising Strict Governance over the Party (in Chinese)" [D]. Central Party School of the Communist Party of China, 2019.

[6] Ying, Du. "Analysis on the Scientific Meaning of Exercising Strict Governance over the Party (in Chinese)". New West [J], Vol. 12, 2020, pp 74; 61. 